Discussion Paper No. 867

\title{
CASTE COMPARISONS: \\ EVIDENCE FROM INDIA
}

\author{
Xavier Fontaine \\ Katsunori Yamada
}

March 2013

The Institute of Social and Economic Research Osaka University

6-1 Mihogaoka, Ibaraki, Osaka 567-0047, Japan 


\title{
Caste comparisons: evidence from India *
}

\author{
Xavier Fontaine $^{\dagger} \quad$ Katsunori Yamada ${ }^{\ddagger}$
}

\begin{abstract}
The caste issue dominates a large part of India's social and political life. Caste shapes Indians' identities, and strong tensions exist between castes. This paper evaluates how caste-based comparisons may be exacerbated in such a conflictual context. Using subjective well-being data from an original panel survey, together with a national representative survey on expenditure, we find that both within-caste comparisons and between-rival-caste comparisons reduce well-being. Between-caste comparisons affect well-being three times more than within-caste comparisons. In absolute value, an increase in rival castes' expenditure affects well-being as much as own expenditure. These findings highlight the strength of comparisons between rival castes. Yet this comparison scheme turns out to be asymmetrical: only low castes care about the economic successes of their rivals, and only high-caste Indians compete with their fellows.
\end{abstract}

keywords: Subjective Well-being; Relative Utility; Caste classes; India; Panel Data

${ }^{*}$ The previous version of the paper was circulated under the titles of "Economic Comparison and Group Identity: Lessons from India". We are grateful to Shinsuke Ikeda, Fumio Ohtake, and Yoshiro Tsutsui for allowing us to use original data from "Survey on Preferences toward, and Satisfaction with, Life" of Osaka University. We are also grateful to the CEPREMAP and the India Research Group for providing us the Indian National Sample Survey data. We would like to thank Alpaslan Akay, Andrew Clark, Ashwini Desphpande, Rakesh Gupta, Clément Imbert, Claudia Senik, Zahra Siddique and Pankaj Verma for their helpful comments, as well as the participants of the World-Bank / IZA 2012 conference. Financial support provided from JSPS research fund KAKEN (24683006), is appreciated. Any remaining error is the sole responsibility of the authors.

${ }^{\dagger}$ Paris School of Economics and Sciences-Po. Corresponding author: xavier.fontaine@sciences-po.org

${ }^{\ddagger}$ ISER, Osaka University and MOVE, Universitat Autonoma de Barcelona 


\section{Introduction}

India is one of the rare countries with a clear social stratification. Identity is deeply rooted in caste at birth. Caste also largely defines position in society and the economy. Importantly, there is strong antagonism between castes. This antagonism often takes the form of discrimination, and sometimes violence. In addition, low castes have called for and are still calling for - reservations in education and the labor market to offset their situation.

This paper aims at evaluating whether caste-based comparisons are exacerbated in this environment. While many studies have established that individuals' well-being can be affected by the consumption/income of others (see Clark et al. 2008 for a survey), a relatively newer, and still open, question is if people with specific characteristics tend to compare themselves to certain types of rivals. This question is answered in part by Clark and Senik (2010) for European countries. India provides rare material to contribute to this line of research, as this country is one of the very few to be characterized by welldefined social groups and strong between-group tensions.

We use subjective well-being data to assess the strength of within and between-caste comparisons in India. More specifically, we make joint use of two data sets. The first one is an original urban panel survey for India conducted by Osaka University, Japan. A nice advantage of the survey is that it contains a happiness question, making it a rare example among surveys conducted in developing countries. The second data set is a large, representative Indian population survey. This second survey enables us to estimate the expenditure of the groups to which respondents are likely to compare themselves.

Our main results are threefold. Firstly, within-caste comparisons affect well-being negatively. This result suggests that expenditure by others from the same caste triggers envy more than it acts as a positive signal about own future consumption. This finding differs from what might have been expected in such a rapidly growing and changing country (Senik 2004, Senik 2008). Secondly, Indians view the rival castes' economic situation enviously. Between-caste comparisons are unexpectedly strong and, in absolute value, comparisons to rival castes affect well-being as much as own expenditure does. We found that they matter for happiness three times more than within-caste comparisons. Thirdly and most importantly, this comparison pattern appears to be asymmetrical: low castes indeed compare themselves to higher castes, but the reverse is not true. Besides, within-caste comparisons are mostly made by members of high castes. These results hold both when pooling the cross-sections and when adding individual fixed-effects into the 
regression.

The rest of the paper is organized as follows. The next section introduces our conceptual framework. After providing some background elements on the Indian caste system and on the tensions in this society, we discuss the importance that economic comparisons may have in this society. We then review the existing literature on comparisons in India, as well as on between-group comparisons in other countries. The third section details our data sets, as one of our data sets is original. The fourth section provides empirical results and the last section concludes the paper.

\section{Research Background}

\subsection{A Conflictual Caste Society}

Although 3,000 years old, the caste system continues to play a central role in India. ${ }^{1}$ This system divides Indians into four classes (varna) and thousands of small communities (jati). The first Indian Constitution (1950) groups the different jati into four broader categories, depending on the level of disadvantage and social stigma they face. This typology simplifies the study of caste inequalities, and will be used throughout this paper. To be specific, caste determines an individuals level of pureness. First, the Scheduled Castes ("untouchables", or Dalits) and the Scheduled Tribes (the tribals) are considered as "impure". Above them are the Other Backward Castes. Even though the castes composing this latter category are mostly considered as "pure", they are still beneath the rest of the population in the caste hierarchy, and suffer from the caste system. Lastly, the rest of the population is categorized as the Other.

This caste system is not just a clustering. It is a social ordering. Caste profoundly influences one's role and position in society (occupation, marriage, with whom one can interact, etc.). For example, for an orthodox Hindu from the highest castes, interacting with low-caste members may even soil purity. As a matter of fact, Indians still mostly marry within their own jati (Munshi and Rosenzweig (2006)). This rigid hierarchy is a source of conflict between the classes, and generates massive economic inequalities. It translates social inequalities into economic inequalities, because low-paid "impure occupations" (cleaning, undertaking, etc.) are reserved for lower castes.

Despite large reservations for the disadvantaged castes in education and the admin-

\footnotetext{
${ }^{1}$ This section draws substantially on Susan Bayly's 2001 general survey of the recent history of India as a caste society.
} 
istration since the 1950s (Bayly (2001), chapter 7), between-caste economic disparities remain striking. In terms of per capita household expenditure, Indians from higher castes consume on average $63 \%$ and $46 \%$ more than, respectively, Scheduled Tribes and Scheduled Castes, ${ }^{2}$ and $27 \%$ more than the Other Backward Castes. ${ }^{3}$ A large body of literature documents the discrimination from which low-caste members suffer. On the labor market, for example, the persistency of this discrimination has been assessed using both non-experimental (e.g. Banerjee and Knight (1985)) and experimental methods (testing methods: Banerjee et al. (2009), Siddique (2011)). Low castes also face discrimination on the housing market. ${ }^{4}$ Yet disadvantaged castes actively struggle to extend the reservation policies they benefit from, sometimes even asking for quotas in the private sector. ${ }^{5}$ Symptomatic of these tensions are the violent conflicts - or "caste wars" that flare up in rural India on a regular basis. ${ }^{6}$ Symptomatic also is the preponderant role of these tensions in India's political life from Independence onwards. ${ }^{7}$

\subsection{Previous Findings on Class Conflicts}

A few papers show relative concerns playing an important role in India based, for instance, on wedding expenditure (Bloch et al. (2004)) and more broadly conspicuous consumption (Khamis et al. (2012)). Carlsson et al. (2009) assess more specifically the role of castebased relative concerns in India, on the basis of a hypothetical choice experiment. They asked respondents to choose between several hypothetical societies for their grandchildren. Each of these societies is characterized by the grandchild's income, the average income for the grandchild's caste, and the average income for society. The authors derive respondents' preferences from the choices made by the respondents. They find the caste's average income to reduce utility, generating evidence of negative within-caste comparisons. Keeping both own and caste income constant, society's average income also affects well-being negatively. The coefficient associated with society's income appears to be higher than the coefficient associated with own caste income, making a case that Indians compare themselves even more to the rest of society (including rival castes) than to people from

\footnotetext{
${ }^{2}$ Authors' computation based on the 2009-10 round of the National Sample Survey, with a sample size of 570000 individuals.

${ }^{3}$ Even in the historically highly egalitarian, anti-caste state of Kerala, Deshpande (2000) finds caste disparities driving overall inequalities.

${ }^{4}$ Bayly (2001), pp. 359-362.

${ }^{5}$ Bayly (2001), chapter 7.

${ }^{6}$ Bayly (2001), chapter 9, pp. 342-358.

${ }^{7} \mathrm{Cf}$. the rise of the anti-reservation party BJP in the 80s and 90s (Bayly (2001), pp.296-300).
} 
their own caste.

A few other papers also seek to find out which groups individuals compare themselves to, although not in India. In European countries, Clark and Senik (2010) use a survey in which respondents were directly asked to whom they compare themselves, and find that Europeans compare themselves predominantly to their colleagues. Another trend in the literature includes the income/consumption level of plausible reference groups in the well-being equation to check for between-group comparisons. Using this methodology, Kingdon and Knight (2007) study income comparisons in South Africa, finding evidence of between-race comparison. Jiang et al. (2011) and Akay et al. (2012) focus on the relation between rural-to-urban migrants and urban "natives" in China. All three papers conclude similarly that, whereas within-group comparisons affect well-being negatively, between-group comparisons make people feel they are better off. This phenomenon can be understood from the point of view that the other group's economic situation acts as a positive signal about the future level of income in one's own group.

\subsection{Specification and Prediction}

In keeping with the literature, we consider the standard relative utility function:

$$
U_{i}=\beta_{y} \ln \left(y_{i}\right)+\beta_{c} \ln \left(y_{\text {caste }_{i}}\right)+\beta_{r} \ln \left(y_{\text {rival }_{i}}\right)+\beta X_{i t}
$$

where $y_{i}$ stands for $i$ 's own expenditure, $y_{\text {caste }_{i}}$ represents $i$ 's caste expenditure level, $y_{\text {rival }_{i}}$ is the expenditure level in the rival castes, and $X_{i t}$ stands for a set of socio-demographic characteristics. This logarithmic-type specification is widely used to model relative utility. ${ }^{8}$ Section 4 details the specification of each variable.

We saw in section 2.1 that caste class conflicts are between the "pure" and the "impure." Hence, caste rivalry is defined as Other Castes (i.e. higher castes) versus the rest of the Scheduled Castes, Scheduled Tribes and Other Backward Castes. It is true that, to some extent, some Indians from the Other Backward Castes have seen the Scheduled Tribes as a threat. Tensions are also known to exist between Other Backward Castes and Scheduled Castes. ${ }^{9}$ However, due to the limited size of our sample, this paper sticks to the main focus of "pure" vs. "impure."

In the specification, our prime interest is with the sign of $\beta_{c}$ and $\beta_{r}$. The sign of $\beta_{c}$ is hard to predict. The envy and conspicuous consumption theories (Veblen (1899),

\footnotetext{
${ }^{8}$ See Clark et al. (2008) for a development of the model and a literature review.

${ }^{9}$ See Bayly (2001), chapter 9 for this point.
} 
Duesenberry (1949)) posit that an increase in others' expenditure makes one feel deprived, thus decreasing well-being. In this case, $\beta_{c}<0$.

Conversely, well-being may actually increase with own caste expenditure. ${ }^{10}$ This may happen when people take others' consumption to predict their own future level of expenditure. In that case, the higher the level of expenditure in the caste, the higher the expected level of own expenditure. Because expectations improve, well-being increases as well (Hirschman and Rothschild (1973); see Card et al. (2012) for a formalization). When this informational effect overwhelms envy, $\beta_{c}>0$. These two effects may also cancel each other out $\left(\beta_{c}=0\right)$.

Within-caste insurance mechanisms might also partly offset the negative feelings triggered by envy, not forgetting altruism (or fellowship feelings) toward people from the same caste. $^{11}$

The impact of rival castes' expenditure is also hard to predict. The literature often assumes that comparison occurs among similar people. In India, however, caste rivalries appear so important (section 2.1) that we could expect $\beta_{r}<0$. Some signal effect may, however, also exist. Because occupation is partly determined by caste, castes are complementary rather than substitutes. Improvements in a given caste's economic conditions may thus act as a signal for its rivals as well. In this case, we could also have $\beta_{r}=0$ or $\beta_{r}>0$. However, there are obviously no between-caste informal insurance mechanisms, nor should any "between-rival-caste" fellowship feelings be expected.

In a next stage, we study separately the relative utility functions of low castes and higher castes. In a 1949 article, Duesenberry posited that comparisons are mostly upward looking. Individuals at the bottom of the social ladder do indeed compare themselves to those above them, but individuals at the top of the ladder do not focus on those below them. In India, the social hierarchy is strict and well-known. Following Duesenberry's logic, only low castes should compare themselves to higher castes.

The intensity of within-caste comparisons may also vary with the caste. This could happen where the intensity of, and balance between, envy and signal / fellowship / insurance mechanisms differs from low castes to higher castes.

\footnotetext{
${ }^{10}$ We draw here from the rich set of explanations developed in Kingdon and Knight (2007).

${ }^{11}$ Envy has often been found to dominate the informational effect in developed countries (Clark et al. (2008), Card et al. (2012)). In developing countries, the evidence is mixed (Clark and Senik (2011)).
} 


\section{Databases}

Our analysis makes joint use of two databases. The first is the "Survey on Preferences toward, and Satisfaction with, Life" (SPSL). This survey comprises a three-year panel collected in six of the ten largest Indian cities (Delhi, Mumbai, Bangalore, Chennai, Kolkata, and Hyderabad) in January 2009, 2010 and 2011, covering 1,857, 1,280, and 1,037 respondents, respectively. Fewer observations than these are usable for regressions due to missing survey response information and inconsistent answers across waves. The data was collected in keeping with the following design. Each city was divided into four areas. Fifteen residential districts were randomly selected in each area. Indigenous interviewers were sent to interview five subjects face to face in each residential district. Interviewers were free to choose on which door to knock, but they were required to comply with two rules: (i) they could not interview a subject living next to other subjects, (ii) the distributions of gender and age category in the collected data set had to be as designed. For the surveys in 2010 and 2011, interviewers went back to the subjects' homes if they had not moved.

In addition to demographic questions covering age, gender, years of education, monthly and annual household expenditure levels, caste information and so forth, ${ }^{12}$ the questionnaire contained the following happiness question:

Overall, how happy would you say you are currently? Using a scale from 0 10 where 10 is very happy and 0 is very unhappy. How would you rate you current level of happiness?

The caste information in the SPSL calls for caution for two reasons. First, the first wave did not collect any information on caste. We thus have to extrapolate this information from the subsequent two waves of data. This should be fine since caste membership is exogenously assigned at birth. Second, a sizable part of the SPSL sample changed caste between the second wave (January 2010) and the third wave (January 2011). Specifically, $38 \%$ of observations concern those respondents who changed their caste in the course of the survey. We call these respondents "movers". These changes are surprising, as they do not occur for other variables such as education or gender. We hypothesize these changes to be due to the announcement (May 2010) of the first Caste Census since 1931. Low caste members indeed suffer from a strong stigma. Yet, at the same time, they benefit from

\footnotetext{
${ }^{12}$ The definition of castes in the survey took up the definition in the National Sample Survey for comparability.
} 
extensive affirmative action programs (mostly quotas in administration and education). For that reason, people may be willing to manipulate their caste identity (from low caste to a higher caste or vice versa), especially when the government is known to be collecting this information. Some respondents may have confused the SPSL with this Caste Census, consequently deciding to adjust their caste identity. ${ }^{13}$

For that reason, in the following analyses we define respondents' castes as they were given in the wave prior to the announcement of the Caste Census (i.e. the second wave). For the regression analyses, as a robustness check, we tried regression where we dropped all the respondents who changed caste in the course of the survey. We obtained the same results as with the whole sample, which suggests that movers do not raise sample selection problems (see section 4.2).

When using the abovementioned happiness equation, we need proxy variables for others' expenditure levels. This calls for the second data set, which has a greater number of observations: given the small sample size of the SPSL, it is not a good idea to compute reference expenditure levels within the data set for the range of cells defined by individual characteristics. Thus we need the second database. We make use of the "Employment and Unemployment Survey" by the National Sample Survey Office, which is a part larger, socially representative survey program called the National Sample Survey (NSS). The last two waves of this survey were collected from July 2007 to June 2008, and from July 2009 to June 2010 respectively (with respective sample sizes of about 750,000 and 460,000). See Imbert and Papp (2013) for more survey details.

When interviewing a household, the NSS measures average monthly household expenditure for the previous year. We thus match the January 2008 - June 2008, July 2009 - December 2009, and January 2010 - June 2010 monthly household expenditure information from the NSS with the 2009, 2010, and 2011 waves of the SPSL respectively. In the six cities we study, the sample sizes of these NSS subsets are 9,712, 6,731 and 6,561 respectively. All our computations use the weights provided in the NSS. The average number of NSS observations used to compute the median household expenditure level in each reference group for each year can be found under each regression table. When performing the main regression described in the previous sub-section, this number is 32 for the within-caste comparison variable and 26 for the between-caste variable.

Table 1 compares the SPSL and the NSS samples with respect to the main population

\footnotetext{
${ }^{13} \mathrm{~A}$ small body of literature exists on the manipulation of caste identity to obtain caste advantages. See Cassan (2012).
} 
characteristics we are interested in. ${ }^{14}$ The median level of household expenditure is fairly similar in both samples. The caste distribution in the SPSL appears to be partly imbalanced, with the share of Scheduled Tribes giving cause for concern: they represent $8.33 \%$ of the SPSL, and $1.26 \%$ of the NSS. The distribution of education is not equal across the two samples, but there is no clear shift in general education between them. The sample from the SPSL also appears to be significantly older.

Perfect representativeness of the sample answering the happiness question is not necessary to recover the parameters from the utility function. The sample used should, however, resemble the general population enough to avoid getting a result fallaciously driven by an over-represented sub-population. Hence the concern about the Scheduled Tribes, who are clearly over-represented in our sample. For that reason, we test the robustness of our result to the exclusion of these respondents, and we are happy to report that the results obtained in this paper are robust to the exclusion.

\section{Empirical Results}

In this section, we estimate the happiness equation (1), but first consider a variation in the definition of the reference expenditure variables. In keeping with the literature, we include only one reference expenditure variable in the happiness equation, by considering the reference group to be "similar others" (Clark and Oswald 1996) irrespective of the respondents' castes. We consider the cell defined by age bracket, level of education and location, which is the same as Ferrer-i-Carbonell's (2005) definition of the reference group. The reference variable we include into the regression, $\log \left(y_{\text {general }_{i t}}\right)$, is thus defined as the logarithm of the median real household expenditure level for those who share $i$ 's level of education, age, and location during year $t$. This first stage analysis is called "general comparison" because we do not cluster the reference group by caste.

We then add caste information, bringing $\log \left(y_{\text {caste }_{i t}}\right)$ and $\log \left(y_{\text {rival }_{i t}}\right)$ into the regression instead of $\log \left(y_{\text {general }_{i t}}\right)$. Here, again, we focus on how individuals compare themselves to people similar to them, both in their own caste and in rival castes. The variable $\ln \left(y_{\text {caste }}\right)$ $\left(\log \left(y_{\text {rival }_{i t}}\right)\right)$ is thus defined as the logarithm of the median real household expenditure

\footnotetext{
${ }^{14}$ We restrict the NSS sample to individuals matching the SPSL restrictions: only people over 20, living in one of the six cities studied in the SPSL. For the sake of simplicity, we compare the SPSL with the last wave of the NSS. In the SPSL, the sampling procedure is designed to be random at city level. The number of individuals drawn from each city is, however, the same by design. To ensure comparability with the NSS, we thus weight each observation according to the share of its city among the six cities in which respondents live.
} 
level for those in $i$ 's caste (rival castes) who share $i$ 's level of education, age, and location during year $t$. In constructing these reference expenditure variables, we consider median household expenditure at year $t$ rather than the average. The median is used because it is less sensitive to outliers. See Clark et al. (2009) on this point.

In a last stage, we run the same regression separately on low and higher castes to check whether low and higher castes differ in the way they compare themselves to one another.

The variables determining the reference groups are defined as follow. Education is defined by seven categories, from "illiterate" to "graduate and above" (see table 5 for details). Three age groups are considered, each containing $1 / 3$ of the adult population in the cities we study. The happiness survey's respondents live in six cities: Bangalore, Chennai, Delhi, Hyderabad, Kolkata and Mumbai. Respondents can be Scheduled Castes, Scheduled Tribes, Other Backward Castes or Other (i.e. higher castes). These variables are also added as covariates in the regression, together with labor force status, number of children, family status, gender and wave.

Our main analyses use pooled cross-sections OLS. In this case, the standard errors are clustered at the respondent's peer group level. We then add individual-specific fixed-effects to exploit the panel structure of the data set, and check the consistency of the results. The

fixed-effect and pooled-OLS regressions actually generate very similar results, in terms of both sign and significance. However, due to the small sample size of our SPSL dataset, we prefer the results for pooled OLS since adding fixed-effects into the regressions attenuates the variance in the data, and thus increases the variance in the estimated coefficients, which in turn artificially inflates some coefficients. See Luttmer (2005) for potential problems in fixed effects regressions of happiness equations.

\subsection{Findings}

Table 2 displays our main results. As mentioned above, we first consider the general setting in which the reference group is defined irrespective of the respondents' castes, by taking Ferrer-i-Carbonell's (2005) definition of the reference group. This regression gives us a general idea of the impact of comparisons in India. The average number of observations used to calculate reference expenditure is 63 .

The first column of Table 2 suggests that others' expenditure reduces happiness sharply, with a statistical significance of $1 \%$. This result is consistent with findings in China (Knight and Gunatilaka (2011)), for instance, but contrasts with observations in 
former communist countries during the transition period (Senik 2004, 2008). 15 Remarkably, comparisons appear to affect well-being to the same extent as own household expenditure does.

The second column factors in the comparison effects whereby respondents may compare themselves differently to people from their own caste than to people from rival castes. We consequently split the reference group into two, replacing $\log \left(y_{\text {general }_{i t}}\right)$ with our above-defined within-caste and between-castes comparison variables $\log \left(y_{\text {caste }}\right)$ and $\log \left(y_{\text {rival }_{i t}}\right)$.

As described in section 2.3, comparisons with similar others within the caste could be expected to have a null or maybe positive impact. Given that India is a rapidly changing country, we could expect Indians to take others' expenditure to predict their own future consumption. The "informational effect" could thus be strong enough to offset envy. Similarly, caste defines identity so strongly that we could expect close caste fellowship feelings, which could again override within-caste jealousy. We, however, found that comparisons with similar others within the caste appear to affect well-being negatively $\left(\hat{\beta}_{c}<0\right)$. Envy hence appears to be stronger than fellowship feelings and informational effects. The fact that the coefficient is significant at $10-\%$ tends to mitigate this conclusion, but we will see below that within-caste comparisons do actually matter for half the caste hierarchy.

The rival castes' economic successes also appear to enter negatively into the well-being function. Between-caste comparisons indeed have a large, negative, 1\%-significant impact on well-being $\left(\hat{\beta}_{r}<0\right)$.

Between-castes comparisons appears to reduce well-being remarkably more than withincaste comparisons (the difference between the two coefficients is significant at a $5 \%$ level in a two-sided test). This result evokes Carlsson et al.'s finding: the authors find own caste's income to affect well-being less than the average income level in the rest of the society (including rival castes).

Between-caste comparisons even appear to affect well-being as much as own expenditure, in absolute value. This sheds light on very strong relative concerns about rival castes, obviously exacerbated by the tensions structuring the Indian caste system. This finding contrasts with the case of South Africa, where comparisons between black and white seem to increase well-being, and with the case of China, where the same is found for comparisons between migrants and non-migrants. In both these cases, the signal effect appears to be stronger than envy. In India, castes are also very complementary, which

\footnotetext{
${ }^{15}$ See Clark and Senik (2011) for a general review of the importance of relative feelings of disadvantage in developing countries.
} 
makes it plausible for rival castes' expenditure to act as a strong signal. However, tensions between high and low castes are so strong that envy widely overwhelms this signal effect.

The third and fourth columns of Table 2 present the analysis for low castes and then for higher castes. We find that the relative utility function differs drastically depending on one's position in the caste hierarchy. First, whereas an increase in own caste's expenditure decreases well-being for higher caste members (1\% significance), low-caste members are found to be unaffected by such a change. Within-group economic competition is thus likely to matter more at the top of the caste hierarchy. At the same time, higher castes do not seem to pay so much attention to the economic situation of low castes (small insignificant impact). Strikingly, however, low-caste Indians are strongly, and negatively affected by the economic successes and failures of higher-caste Indians. This result tends to bear out Duesenberry's view that individuals are mostly upward-looking when comparing themselves to others.

\subsection{Robustness Checks}

The validity of the previous results is tested along two main lines. Given that some respondents changed their castes in the course of the survey (see section 3), we have to check that they are not driving the results. We also check whether the results hold when adding individual fixed-effects to the regression.

Non-movers are respondents for which the reported caste has been collected more than once (i.e. who did not drop out during the course of the survey) and who did not change their caste. Table 3 displays the results obtained for this sub-sample. Despite the effect of the smaller sample size on both magnitudes and significance, these figures appear to be pretty similar to what we have found previously.

The results are also found to be robust to the inclusion of individual-specific intercepts. Because adding fixed-effects amounts to centering the variables at the individual level, and due to the sample's small size, the estimates are quite inflated. Table 4, however, shows both signs and significance to be consistent with the previous results. This stability strongly supports our previous conclusions.

Additionally, we test the results' robustness to the exclusion of the Scheduled Tribes, both in pooled-cross sections and with fixed-effects. As evoked in section 3, this category is oversampled. Running the analysis again without Scheduled Tribes does not change the results. 


\section{Concluding Comments}

Individuals are often implicitly assumed to compare themselves to their peers. In the Indian context, however, this view is subject to caution. Strong tensions are known to exist between clearly dissociated social groups, the castes. Consequently, both betweencaste comparisons and within-caste comparisons are likely to be of importance.

Using a unique Indian panel data set, we show that the caste system influences the way Indians compare themselves to one another, and that the comparison scheme is asymmetrical. Only low castes care about the economic successes of their rivals, and only high-caste Indians compete with their fellows. The fact that comparisons between rival castes are made by low-caste Indians bears out Duesenberry's view that individuals at the bottom of the hierarchy compare themselves to those at the top, but that the reverse does not hold. Our results on between-caste comparisons contrast with previous research in South Africa and China. In these countries, between-group comparisons are found to increase happiness. In the case of India, existing tensions between rival castes are very likely to explain this difference: even though low and higher castes are complementary, these tensions are strong enough to lead envy to widely overwhelm the signal effect.

Unlike Linssen et al. (2011), who worked on data on rural India, our data was collected in urban areas in India. While we expected signaling effects to pertain in rapidly growing urban areas, it is interesting that we obtained otherwise. We call for further happiness research in India, as the accumulated evidence in the country is still scarce and our analysis should be conducted again with different data sets.

\section{Appendix}

This section provides the results obtained from a simple happiness regression without including a reference expenditure variable. Table 5 shows the coefficients we obtain both in pooled cross-section OLS and fixed-effect OLS. We focus here on describing the first regression's coefficients.

As expected, log real household expenditure has a positive and very significant impact. Education improves well-being monotonically. Other things being equal (household expenditure included), any labor status appears to be better than working, except being a "housewife or househusband" (97.6\% of people belonging to this category are actually women). The difficult working conditions in developing countries certainly drive much of this result. "Not working" increases well-being as compared to the situation where the 
respondent has a job. This result can be understood by noticing first that this category consists of $70 \%$ of women. It is quite likely that most of these respondents are women at the head of the household, with another woman doing the housekeeping tasks (daughter, daughter-in-law, etc). Consequently, they do not consider themselves as being housewives, and declare themselves to be unoccupied instead.

Having between one and three children does not affect happiness, as compared to having no children. Having more than three children, however, significantly decreases happiness. This pattern is pretty similar to the pattern observed in developed countries. The rest of the family status variables surprisingly do not seem to have any significant impact. Age and gender also appear to have no significant impact. On the contrary, both the place of residence and the year have strong effects on well-being.

Not surprisingly, belonging to one of the Other Backward Castes instead of belonging to a higher caste (omitted category) decreases happiness. However, being neither from a Scheduled Caste nor a Scheduled Tribe has a significant negative impact. This result appears quite puzzling. Interestingly, it is quite similar to what Linssen et al. (2011) obtain. They find that belonging to a Scheduled Caste/Tribe or to an Other Backward Caste has no significant impact on well-being, as compared to belonging to a higher caste. Still, caste influences expenditure and education, which in turn affect happiness. However, once we control for those variables affected by caste membership, caste does not appear to affect well-being as much as might have been expected.

\section{References}

Akay, A., O. Bargain and K. F. Zimmermann, "Relative Concerns of Rural-toUrban Migrants in China," Journal of Economic Behavior \& Organization (2012).

Banerjee, A., M. Bertrand, S. Datta and S. Mullainathan, "Labor market discrimination in Delhi: Evidence from a field experiment," Journal of Comparative Economics 37 (March 2009), 14-27.

Banerjee, B. And J. B. Knight, "Caste discrimination in the Indian urban labour market," Journal of Development Economics 17 (April 1985), 277-307.

Bayly, S., Caste, Society and Politics in India from the Eighteenth Century to the Modern Age, The New Cambridge History of India (Cambridge University Press, 2001). 
Bloch, F., V. Rao and S. Desai, "Wedding Celebrations as Conspicuous Consumption: Signaling Social Status in Rural India," Journal of Human Resources 39 (2004).

Card, D., A. Mas, E. Moretti And E. Saez, "Inequality at Work: The Effect of Peer Salaries on Job Satisfaction," American Economic Review 102 (October 2012), 2981-3003.

Carlsson, F., G. Gupta and O. Johansson-Stenman, "Keeping up with the Vaishyas? Caste and relative standing in India," Oxford Economic Papers 61 (January 2009), 52-73.

Cassan, G., "Identity based policies and identity manipulation: evidence from Colonial Punjab," Working Papers 1214, University of Namur, Department of Economics, December 2012.

Clark, A. E., P. Frijters and M. A. Shields, "Relative Income, Happiness, and Utility: An Explanation for the Easterlin Paradox and Other Puzzles," Journal of Economic Literature 46 (March 2008), 95-144.

Clark, A. E., N. Kristensen and N. Westergård-Nielsen, "Economic Satisfaction and Income Rank in Small Neighbourhoods," Journal of the European Economic Association 7 (04-05 2009), 519-527.

Clark, A. E. And A. J. Oswald, "Satisfaction and comparison income," Journal of Public Economics 61 (September 1996), 359-381.

Clark, A. E. And C. Senik, "Who Compares to Whom? The Anatomy of Income Comparisons in Europe," Economic Journal 120 (05 2010), 573-594.

— - "Will GDP Growth Increase Happiness in Developing Countries?," in R. Peccoud, ed., Measure For Measure: How Well Do We Measure Development? (Paris: STIN, 2011), 99-176.

Deshpande, A., "Does Caste Still Define Disparity? A Look at Inequality in Kerala, India," American Economic Review 90 (May 2000), 322-325.

Duesenberry, J. S., Income, Savings and the Theory of Consumer Behavior (Harvard University Press, 1949). 
FERrER-I-CARBOnELl, A., "Income and well-being: an empirical analysis of the comparison income effect," Journal of Public Economics 89 (June 2005), 997-1019.

Hirschman, A. O. And M. Rothschild, "The Changing Tolerance for Income Inequality in the Course of Economic Development; with a Mathematical Appendix," The Quarterly Journal of Economics 87 (November 1973), 544-66.

Imbert, C. And J. PAPP, "Labor Market Effects of Social Programs: Evidence from India's Employment Guarantee," CSAE Working Paper Series 2013-03, "Centre for the Study of African Economies, University of Oxford", 2013.

JiAng, S., M. Lu And H. SATo, "Identity, Inequality, and Happiness: Evidence from Urban China," World Development (2011).

Khamis, M., N. Prakash and Z. Siddique, "Consumption and social identity: Evidence from India," Journal of Economic Behavior \& Organization 83 (2012), 353-371.

Kingdon, G. G. And J. Knight, "Community, comparisons and subjective well-being in a divided society," Journal of Economic Behavior $\&$ Organization 64 (September 2007), 69-90.

Knight, J. And R. Gunatilaka, "Does Economic Growth Raise Happiness in China?," Oxford Development Studies 39 (2011), 1-24.

Linssen, R., L. van Kempen and G. KraAykamp, "Subjective Well-being in Rural India: The Curse of Conspicuous Consumption," Social Indicators Research 101 (2011), 57-72, 10.1007/s11205-010-9635-2.

Luttmer, E. F. P., "Neighbors as Negatives: Relative Earnings and Well-Being," The Quarterly Journal of Economics 120 (August 2005), 963-1002.

Munshi, K. And M. Rosenzweig, "Traditional Institutions Meet the Modern World: Caste, Gender, and Schooling Choice in a Globalizing Economy," American Economic Review 96 (September 2006), 1225-1252.

SEnIK, C., "When information dominates comparison: Learning from Russian subjective panel data," Journal of Public Economics 88 (August 2004), 2099-2123.

—, "Ambition and Jealousy: Income Interactions in the 'Old' Europe versus the 'New' Europe and the United States," Economica 75 (08 2008), 495-513. 
Siddique, Z., "Evidence on Caste-Based Discrimination," Labour Economics (2011).

Veblen, T., The Theory of the Leisure Class (London: Macmillan, George Allen and Unwin, 1899). 
Table 1: Descriptive statistics, NSS \& SPSL

\begin{tabular}{rr|cc} 
& & NSS & SPSL \\
\hline \hline Caste (\%) & & \\
& Other Backward Castes & 30.06 & 26.39 \\
Scheduled Castes & 13.66 & 15.09 \\
Scheduled Tribes & 1.26 & 8.33 \\
Neo-Buddhists & - & 1.42 \\
Gducation (\%) & General Population & 55.02 & 48.77 \\
Literate, formal schooling < 4 years & & \\
& Illiterate & 12.80 & 12.84 \\
& Primary & 9.71 & 1.34 \\
Middle/upper primary & 14.73 & 24.07 \\
Secondary/higher secondary & 31.44 & 31.24 \\
College, but not graduate & 1.74 & 5.91 \\
Graduate and + & 24.86 & 17.81 \\
& 35 & 44 \\
Median age & & & \\
Median household expenditures (real, 2005) & 5803 & 6083
\end{tabular}


Table 2: OLS regression on happiness, pooled cross-sections, main results

\begin{tabular}{l|l|lll} 
& $\begin{array}{l}\text { General } \\
\text { comparisons }\end{array}$ & $\begin{array}{l}\text { Within \& Between } \\
\text { comparisons }\end{array}$ & $\begin{array}{l}\text { Low castes } \\
\text { only }\end{array}$ & $\begin{array}{l}\text { Higher castes } \\
\text { only }\end{array}$ \\
\hline \hline $\log$ (Household expenditure) & $0.517^{* *}$ & $0.549^{* *}$ & $0.554^{* *}$ & $0.516^{* *}$ \\
& $(0.077)$ & $(0.083)$ & $(0.118)$ & $(0.111)$ \\
$\log$ (General ref. expenditure) & $-0.644^{* *}$ & - & - & - \\
& $(0.216)$ & - & - & - \\
$\log$ (Within-caste ref. expenditure) & - & $-0.150+$ & -0.030 & $-0.877^{* *}$ \\
& - & $(0.080)$ & $(0.086)$ & $(0.228)$ \\
$\log$ (Between-caste ref. expenditure) & - & $-0.608^{* *}$ & $-0.761^{* *}$ & -0.168 \\
& - & $(0.161)$ & $(0.191)$ & $(0.285)$ \\
\hline \hline Num. Obs. & 2908 & 2590 & 1288 & 1302 \\
R-Squared & 0.1728 & 0.1796 & 0.2213 & 0.2105
\end{tabular}

$+\mathrm{p}<0.10,{ }^{*} \mathrm{p}<0.05,{ }^{* *} \mathrm{p}<0.01$

Cluster-robust standard errors in parenthesis - sample clustered by (age category $\times$ education $\times$ city $\times$ caste). Other controls: education, labor force status, number of children, family status, age category, gender, city, caste, wave. Average number of observations used to compute the reference expenditure variables in each cell for each year: first column, 63; second column, 32 and 26; third column, 15 and 32; fourth column, 50 and 20 .

Table 3: OLS regression on happiness, pooled cross-sections, non-movers only

\begin{tabular}{l|l|lll} 
& $\begin{array}{l}\text { General } \\
\text { comparisons }\end{array}$ & $\begin{array}{l}\text { Within \& Between } \\
\text { comparisons }\end{array}$ & $\begin{array}{l}\text { Low castes } \\
\text { only }\end{array}$ & $\begin{array}{l}\text { Higher castes } \\
\text { only }\end{array}$ \\
\hline \hline $\log ($ Household expenditure $)$ & $0.647^{* *}$ & $0.682^{* *}$ & $0.654^{* *}$ & $0.591^{* *}$ \\
& $(0.102)$ & $(0.107)$ & $(0.185)$ & $(0.133)$ \\
$\log ($ General ref. expenditure $)$ & $-0.684^{*}$ & - & - & - \\
& $(0.292)$ & - & - & - \\
$\log$ (Within-caste ref. expenditure) & - & -0.258 & -0.210 & $-0.639^{*}$ \\
& - & $(0.220)$ & $(0.221)$ & $(0.318)$ \\
$\log ($ Between-caste ref. expenditure $)$ & - & $-0.816^{* *}$ & $-1.191^{* *}$ & -0.420 \\
& - & $(0.222)$ & $(0.264)$ & $(0.283)$ \\
\hline \hline Num. Obs. & 1240 & 1151 & 398 & 753 \\
R-Squared & 0.2304 & 0.2535 & 0.3682 & 0.2603
\end{tabular}

$+\mathrm{p}<0.10,{ }^{*} \mathrm{p}<0.05,{ }^{* *} \mathrm{p}<0.01$

Cluster-robust standard errors in parenthesis - sample clustered by (age category $\times$ education $\times$ city $\times$ caste). Other controls: education, labor force status, number of children, family status, age category, gender, city, caste, wave. Average number of observations used to compute the reference expenditure variables in each cell for each year: first column, 58; second column, 41 and 15; third column, 22 and 18; fourth column, 52 and 14 . 
Table 4: OLS regression on happiness, with individual fixed-effects

\begin{tabular}{l|l|lll} 
& $\begin{array}{l}\text { General } \\
\text { comparisons }\end{array}$ & $\begin{array}{l}\text { Within \& Between } \\
\text { comparisons }\end{array}$ & $\begin{array}{l}\text { Low castes } \\
\text { only }\end{array}$ & $\begin{array}{l}\text { Higher castes } \\
\text { only }\end{array}$ \\
\hline \hline $\log$ (Household expenditure) & $0.383^{* *}$ & $0.412^{* *}$ & $0.357^{*}$ & $0.468^{* *}$ \\
& $(0.102)$ & $(0.110)$ & $(0.156)$ & $(0.152)$ \\
$\log$ (General ref. expenditure) & $-0.987^{* *}$ & - & - & - \\
& $(0.191)$ & - & - & - \\
$\log$ (Within-caste ref. expenditure) & - & $-0.329^{*}$ & -0.224 & $-1.296^{* *}$ \\
& - & $(0.133)$ & $(0.149)$ & $(0.261)$ \\
$\log$ (Between-caste ref. expenditure) & - & $-0.918^{* *}$ & $-1.268^{* *}$ & -0.336 \\
& - & $(0.149)$ & $(0.200)$ & $(0.238)$ \\
\hline \hline Num. Obs. & 3340 & 2590 & 1288 & 1302 \\
R-Squared & 0.0567 & 0.0697 & 0.2087 & 0.0660
\end{tabular}

$+\mathrm{p}<0.10,{ }^{*} \mathrm{p}<0.05,{ }^{* *} \mathrm{p}<0.01$

Cluster-robust standard errors in parenthesis - sample clustered by (age category $\times$ education $\times$ city $\times$ caste). Other controls: education, labor force status, number of children, family status, age category, gender, city, caste, wave. Average number of observations used to compute the reference expenditure variables in each cell for each year: first column, 66; second column, 32 and 26; third column, 15 and 32; fourth column, 50 and 20 . 
Table 5: Pooled and Fixed-effect regressions on happiness, no comparison variable

\begin{tabular}{|c|c|c|c|c|}
\hline & \multicolumn{2}{|c|}{ Pooled OLS } & \multicolumn{2}{|c|}{ Fixed-effect OLS } \\
\hline $\log ($ Household expenditure) & $0.510^{* *}$ & 0.067 & $0.343^{* *}$ & 0.102 \\
\hline Education (omitted: illiterate) & & & & \\
\hline literate but schooling $<4$ years & 0.337 & 0.275 & -0.604 & 1.172 \\
\hline primary & 0.060 & 0.152 & -1.137 & 2.013 \\
\hline middle/upper primary & $0.308^{* *}$ & 0.115 & -0.605 & 1.088 \\
\hline secondary/Higher secondary & $0.416^{* *}$ & 0.115 & -0.620 & 1.192 \\
\hline college, not graduate & $0.449^{* *}$ & 0.165 & 0.329 & 1.799 \\
\hline gradutate + & $0.662^{* *}$ & 0.131 & -0.570 & 1.424 \\
\hline Labor force status (omitted: employed) & & & & \\
\hline not working (excl. housewife/husband) & $0.533^{* *}$ & 0.160 & $0.634^{* *}$ & 0.233 \\
\hline housewife/husband & 0.069 & 0.104 & 0.245 & 0.165 \\
\hline retired & $0.383^{* *}$ & 0.127 & $0.538^{* *}$ & 0.206 \\
\hline student & 0.300 & 0.183 & $0.570^{*}$ & 0.269 \\
\hline \# of children category (omitted: no children) & & & & \\
\hline $1-3$ & -0.059 & 0.117 & 0.051 & 0.208 \\
\hline$>3$ & $-0.294+$ & 0.150 & 0.014 & 0.322 \\
\hline Single without parents & -0.379 & 0.285 & 0.036 & 0.443 \\
\hline Single with parents & 0.106 & 0.178 & -0.032 & 0.256 \\
\hline Married with parents & -0.079 & 0.081 & $-0.306^{*}$ & 0.136 \\
\hline Other & -0.122 & 0.092 & -0.157 & 0.136 \\
\hline Age category (omitted: 20-27) & & & & \\
\hline $28-41$ & -0.076 & 0.118 & 0.481 & 0.413 \\
\hline $42+$ & -0.153 & 0.119 & 0.419 & 0.503 \\
\hline Gender (omitted: male) & & & - & - \\
\hline female & 0.017 & 0.097 & - & - \\
\hline City (omitted: Delhi) & & & - & - \\
\hline Mumbai & $0.506^{* *}$ & 0.113 & - & - \\
\hline Bengaluru & $-0.739^{* *}$ & 0.144 & - & - \\
\hline Chennai & 0.165 & 0.116 & - & - \\
\hline Kolkata & $-0.799^{* *}$ & 0.110 & - & - \\
\hline Hyderabad & 0.108 & 0.110 & - & - \\
\hline Wave (omitted: 2009) & & & & \\
\hline 2010 & $0.362^{* *}$ & 0.075 & $0.266^{* *}$ & 0.085 \\
\hline 2011 & $0.700^{* *}$ & 0.077 & $0.601^{* *}$ & 0.092 \\
\hline Other Backward Castes & $-0.270^{* *}$ & 0.089 & - & - \\
\hline Scheduled Castes & -0.030 & 0.098 & - & - \\
\hline Scheduled Tribes & -0.134 & 0.133 & - & - \\
\hline Neo-Buddhists & 0.101 & 0.278 & - & - \\
\hline intercept & $2.342^{* *}$ & 0.604 & $3.846^{* *}$ & 1.344 \\
\hline $\begin{array}{l}\text { Num. Obs. } \\
\text { R-squared }\end{array}$ & $\begin{array}{r}29 \\
0.16\end{array}$ & & & \\
\hline
\end{tabular}

Standard errors in the right columns. 